\title{
Research on how to build new Foreign Trade competitive advantages of Ningbo by using the "Internet +"under the innovation-driven Background
}

\author{
Wenhui $\mathrm{Ma}^{1, \mathrm{a}}$ \\ ${ }^{1}$ No.899. Xueyuan Road, Ningbo Dahongying University, Yinzhou District, Ningbo City,Zhejiang \\ Prov, China \\ a echoamy123@163.com
}

Keywords: Innovation, "Internet +", Competitive advantages

Abstract. Implementation of innovation-driven development strategy, speed up industrial upgrading, to seize the commanding heights of economic competition has become the focus of a new round of global economic development. "Internet +" lead to industry form has undergone major changes. In innovation-driven context, the "Internet + trade" with its new concept, a new model for promoting the development of foreign trade in Ningbo new engine, and to foster the formation of new competitive advantages the city's foreign trade will play an important role.

\section{Introduction}

Attaches great importance to and national policy helped to promote cross-border electronic commerce development played an important role. Ningbo is the one of the first pilot city for cross-border electricity business services, in October 2015, Ningbo issued "about accelerating Ningbo cross-border e-commerce development guidance. Under the background of innovation drive, "Internet + foreign trade" with its new ideas, new model become the new engine to promote the development of Ningbo foreign trade, to foster and form new city foreign trade competition advantages will play an important role.

\section{The traditional advantage analysis of Ningbo foreign trade industry}

\subsection{Location advantage}

Ningbo port has a unique geographical advantage, foreign fan radiation, for east Asia and the Pacific rim. Sea to Hong Kong, Taiwan, Japan, South Korea and other countries and regions of distance within 1000 nautical miles. Oceania and other port has direct radiation condition, is China's coastal cities in east Asia and the Pacific rim's ocean radiation ideal base. Internally in the Chinese mainland coastal and the Yangtze river golden waterway of the "T" type junction, north and south direction connection all of China's coastal ports, what direction to the Yangtze river all the ports along the river, and can be used rivers through the Beijing-Hangzhou grand canal and other channels, direct covering China's economically developed eastern China and the whole Yangtze river valley, and China's coastal port city, the traffic is very convenient.

\subsection{Industrial advantage}

Ningbo foreign trade and the electricity industry advantage is very outstanding. As the national top ten foreign trade city, the Ningbo foreign trade industry correlation is over 60\%, has more than 20000 foreign trade import and export enterprises. Among them, more than $90 \%$ of the foreign trade enterprises to use the Internet to carry out business activities, the number of foreign trade enterprise Ningbo electric business activities account for nearly $10 \%$ of the total number of national foreign trade electronic retailing, leading the similar cities in China. Ningbo bonded area has been formed, oak social security tax logistics center, Lishe airport logistics park, Meishan bonded port area such as cross-border electricity imports base and cross-border trade e-commerce industrial park, Ningbo Haishu electric mall Jiangbei park, Yuyao electronic commerce industrial park such as cross-border electricity export industries concentrated area as the main body, to Ningbo international conference and exhibition center, Ningbo bonded area, Meishan bonded harbor area. The year 2015, Ningbo cross-border electricity pilot business imports and exports totaled 8.14 billion yuan, 2.93 billion 
yuan, including import export 5.21 billion yuan (\$800 million).

\subsection{Policy advantage}

Ningbo has the only bonded zone in Zhejiang province, at the same time, has given priority to with processing and manufacturing, bonded logistics, area of 3 square kilometers of export processing zone. And enjoy the "exemption certificate, tax exemption, bonded" policy, implement "within the territory of the commissioner of works," is the highest degree of opening to the outside world and at home at present operation mechanism is the most flexible, policy is one of the most favorable special economic zone. In addition, more free trade zone, export processing zones, bonded logistics park and port into an organic whole, planning area of 7.7 square kilometers of Meishan bonded port. The bonded port area is China's fifth bonded port area. Since October 1, 2013, Ningbo has become one of the first pilot city cross-border electricity.

\section{Under the innovation-driven context, the "Internet + " on the new competitive advantages in foreign trade in Ningbo}

\subsection{Upgrade the industrial chain advantage}

"Internet +" will drive the Ningbo Foreign Trade in manufacturing increased from the low end of the international industrial chain to high-end, with the penetration of the Internet industry to equipment manufacturing industry and new energy, new materials will also promote the Ningbo high-end manufacturing development of. Get personalized via the Internet and the diverse needs of consumers, manufacturers may have their own brands overseas outlets to meet consumer demand for products, profit margins and its products can be increased from $5 \%$ to $10 \%$ to $30 \%$ to $40 \%$. The next 10 years, change the value chain to reshape global trade patterns of production, Ningbo can rely on "Internet +" mode to enhance industrial upgrading in the global value chain.

\subsection{Enhance market environmental advantage}

"Internet + trade" There is in the customs administration, foreign exchange payments, commodity inspection, business certification, etc. with the traditional way of foreign trade significant difference, requires the use of the Internet of Things, cloud computing, big data technology, updating business information industry development ideas, and real play a decisive role in the market and better play the role of government. With the improvement of relevant laws and regulations, institutional mechanisms, policy environment, the standard system, the support system will inevitably impact on the formation of the traditional foreign trade regime. To meet the "Internet + foreign trade," the development of traditional trade management also needs to make reforms will accelerate the adjustment of the national foreign trade system and management mechanisms, so as to enhance the level of China's foreign trade management services, trade facilitation and promote the formation of institutional mechanisms.

\subsection{Promote comprehensive service advantage}

"Internet +" spawned a comprehensive foreign trade rise of the service sector. Based on the increase "Internet $+"$ in the foreign trade integrated service providers and third-party service platform, these integrated services business through the integration of industrial chain, trade chain, chain of custody and data link, on the basis of existing information and transaction services to cover the payment, logistics, credit, product quality insurance and financial direction, provide a full range of integrated online services for the entire process of international trade. Such as Ningbo famous trade service platform "through the WTO." Through the "online + offline resources and services" model, using the Internet means to actively extend information, logistics, customs clearance, insurance, finance and other functions, to provide SMEs with one-stop import and export services to small and micro enterprises dare to face Order orders, while still enjoying the platform integration of resources and price concessions, improve bargaining power and marketing capabilities.

\section{4."Internet + " to Ningbo Foreign Trade new competitive advantages of Forward Path}

\subsection{Create a market environment and ecological environment}

We should unify our thinking, the formation of "Internet + " consensus, ideas and public opinion 
environment, establish and improve laws and regulations, policy support, intellectual property protection, information security, technical standards, tax administration, the statistical monitoring support system. We should be in the registration, approval, taxation and other aspects of the process to promote e-government, the formation of the government management upgrade "Internet + " under which we should regulate "Internet +" innovation and entrepreneurship competition in order to eliminate the monopoly of the market. We should expand the information technology and the level of openness to encourage foreign investment in network infrastructure. We should develop a variety of preferential policies to enhance the attractiveness of the material benefits, industrial structure, in order to cause a variety of high-tech talent, communication and cooperation, and provide a vast space.

\subsection{Cross-border logistics and distribution system to create (Overseas warehouse)}

We should build cross-border e-commerce development and adapt to the modern courier, logistics and supply chain system the whole process, to further improve the postal service, express delivery hub function, encourage transportation, warehousing and other traditional logistics enterprises upstream and downstream extension services, strengthen distribution center and network-building, research and development and promotion of cross-border diversification of distribution logistics information system service system. Through the establishment of logistics alliance and global logistics services network, providing a full range of cross-border electricity supplier logistics services and integrated logistics services and foreign trade, to create an international logistics group.

\subsection{Enhance brand awareness}

We should encourage B2C business innovation and cooperation, into overseas retail system, gradually standardized management, logistics management and specialized production intensification. We should guide more brands and manufacturing advantages of cross-border online retail enterprises to enter the market, change the "Made in China" products of low quality image. We should encourage cross-border online retail platform in line to the world-class service providers, competition and the quality of goods and services, and help SMEs to create their own brands, by improving product quality and user experience, network maintenance and promotion of good brand, enhance the brand image and product profit margins. We should guide cross-border online retail platform has become an overseas Chinese consumers about quality brand windows, "Made in China" has become an important way to brand and creative direction of China.

\section{Conclusion}

Cultivate new competitive advantages in foreign trade requires long-term efforts, while cross-border e-commerce is the new competitive advantages in foreign trade of the best ways to improve in the short term. Active cross-border e-commerce still highlight the advantages of foreign trade in Ningbo, including market advantage, industrial chain advantage, supply chain and other advantages. Although the present situation of cross-border e-commerce in foreign trade in Ningbo, the proportion is not big enough, pulling effect on trade is not obvious, but in the long term, cross-border e-commerce consumer-oriented development concept, flexible and innovative development model.

\section{Acknowledgements}

This work was financially supported by the Ningbo Science and Technology Bureau (2016A10020).

\section{References}

[1] "' Internet + "action guidance," the State Council. July 2015

[2] "Guidance on facilitating cross-border e-commerce healthy and rapid development," the State Council. July 2015

[3] "Guiding Opinions on Accelerating cross-border e-commerce development in Ningbo City," Ningbo Municipal Government. October 2015 
[4] "On accelerating the development of e-commerce to develop new economic dynamism of opinions", the State Council. May 2015 